\title{
Konten Lowongan Pekerjaan Bidang Administrasi Perkantoran di Masa Pandemi Covid-19 di Indonesia
}

\author{
Tio Prasetio \\ Universitas Budi Luhur \\ Jalan Raya Ciledug Petukangan Utara Jakarta Selatan, Indonesia \\ e-mail: tio.prasetio@budiluhur.ac.id
}

\begin{abstract}
Informasi Artikel Diterima: 06-07-2021 Direvisi: 12-07-2021 $\quad$ Disetujui: 23-07-2021
Abstrak - Pandemi Covid-19 memberikan dampak terhadap jumlah tenaga kerja di Indonesia. Perusahaan mulai memaksimalkan penggunaan teknologi, karena hampir semua pekerjaan dilakukan oleh karyawan dari rumah (secara daring). Banyak karyawan kehilangan pekerjaan karena pemutusan hubungan kerja. Mengakibatkan meningkatnya jumlah pengangguran. Sulitnya mencari pekerjaan menjadi sebuah tantangan bagi pelamar kerja untuk memperhatikan kualifikasi kebutuhan perusahaan di saat pandemi Covid-19. Tujuan penelitian ini yaitu untuk mengetahui identifikasi kebutuhan perusahaan dalam merekrut calon karyawan di masa pandemi Covid-19 berdasarkan info lowongan pekerjaan bidang administrasi perkantoran. Metode yang digunakan dalam penelitian ini adalah metode konten (metode isi). Sampel penelitian sebanyak 50 buah info lowongan pekerjaan dari situs online untuk profesi di bidang administrasi perkantoran. Hasil penelitian menunjukkan bahwa kebutuhan perusahaan saat merekrut calon karyawan untuk profesi Sekretaris, Staf Admin, dan Personal Assistant lebih mengutamakan sikap kejujuran, memiliki kemampuan komunikasi yang efektif, memiliki pengetahuan dan teknologi, dan dapat menggunakan teknologi (otomatisasi perkantoran). Calon pelamar dapat memaksimalkan pemahaman dan kemampuannya dalam penggunaan teknologi sebagai persyaratan yang dibutuhkan oleh perusahaan di masa pandemi Covid-19.
\end{abstract}

Kata Kunci: Pandemi Covid-19, lowongan pekerjaan, Administrasi.

\begin{abstract}
The Covid-19 pandemic has impact on the number of workers in Indonesia. Companies are starting to maximize the use of technology, because almost all work is done by employees from home (online). Many employees lost their jobs due to layoffs. Resulting in an increase in the number of unemployed. The difficulty of finding a job is a challenge for job applicants to pay attention to the qualifications of the company's needs during the Covid-19 pandemic. The purpose of this study is to identify the company's needs in recruiting prospective employees during the Covid-19 pandemic based on information on job vacancies in the office administration field. The method used in this research is the method of content (content method). The research sample is 50 pieces of job vacancy info from online sites for professions in the office administration field. The results of the study indicate that the company's needs when recruiting prospective employees for the professions of Secretary, Admin Staff, and Personal Assistant prioritize honesty, have effective communication skills, have knowledge and technology, and can use technology (office automation). Prospective applicants can maximize their understanding and ability in using technology as a requirement needed by companies during the Covid-19 pandemic.
\end{abstract}

Keywords: Covid-19 pandemic, job vacancies, Administration.

\section{Pendahuluan}

Indonesia berduka sejak Virus Corona penyebab Covid-19 mulai melanda pada bulan Maret 2020. Tercatat sampai dengan tanggal 03 Juli 2021 sejumlah 60.027 Orang meninggal akibat virus tersebut (https://covid19.go.id/, 2021). Varian virus terus bermutasi dan mulai ditemukan di Indonesia berjenis Covid-19 varian Delta atau dengan sebutan B.1.617.2. Setelah diteliti oleh ahli epidemiologi dunia untuk jenis virus Corona varian baru ini diketahui sangat lebih cepat menular dan menyerang usia anak-anak. Pandemi Covid-19 yang belum berakhir di Indonesia membuat hampir semua aspek kehidupan mengalami perubahan. Kegiatan bekerja di kantor (WFO/Work From Office) berubah menjadi bekerja di rumah (WFH/Work From Home). Kegiatan pembelajaran dilaksanakan secara daring. Kemudian pola hidup masyarakat berubah menjadi lebih bersih dan disiplin dalam menjaga imunitas serta kebersihan diri. Perubahan aspek yang paling berpengaruh dalam bidang ekonomi yaitu penurunan omzet perusahaan-perusahaan di Indonesia yang 
mengakibatkan terjadinya Pemutusan Hubungan Kerja (PHK) dalam jumlah yang cukup signifikan.

Berbasis survei online kepada 87.000 tenaga kerja yang dilakukan oleh Badan Pusat Statistik (BPS) pada bulan Oktober 2020. Didapatkan hasil data sebanyak $82 \%$ tenaga kerja mengalami perubahan penurunan pendapatan akibat pandemi Covid-19. Karyawan dengan sektor kerja yang paling berdampak yaitu bidang hospitality sebesar $85 \%$ dan sektor pariwisata sebesar $82 \%$ (https://merdeka.com/, 2020). Pengaruh Covid-19 terhadap penduduk usia kerja pada semester pertama (Maret s.d Agustus 2020) yaitu adanya karyawan bekerja dengan pengurangan jam kerja berjumlah 24.030.000 Orang dan munculnya pengangguran berjumlah 2.560.000 Orang (https://bps.go.id, 2020). Bertambahnya angka pengangguran membawa dampak peningkatan yang cukup siginifikan bagi orang yang ingin mencari pekerjaan selama pandemi Covid-19. Mayoritas para pelamar kerja mendapatkan informasi lowongan pekerjaan secara online di internet (https://cnnindonesia.com/, 2020). Yaitu melalui situs pencarian kerja seperti jobstreet, linkedin, karir.com, glints, jobs.id, dan indeed. Hal ini dianggap menjadi solusi cepat dan tepat dalam mendukung kebijakan pemerintah dalam menerapkan protokol kesehatan untuk tetap tinggal di rumah dan menjauhi kerumunan serta kebijakan PSBB (Pembatasan Sosial Skala Besar). Jika dibanding mencari melalui media massa cetak atau mendatangi langsung perusahaan-perusahaan, media online lebih fleksibel dalam menginformasikan pekerjaan dan dapat diakses kapan saja serta informasi yang disediakan dalam fitur yang jauh lebih banyak dan lebih update.

Tidak bisa dipungkiri bahwa terjadi penurunan yang drastis mengenai jumlah informasi lowongan pekerjaan di Indonesia selama pandemi Covid-19. Jobstreet Indonesia melaporkan data jumlah informasi lowongan pekerjaan pada bulan April s.d Mei 2020 berdampak signifikan yaitu terjadi penurunan 8.000 iklan lowongan pekerjaan atau turun $73,3 \%$ jika dibandingkan tahun 2019 (https://merdeka.com/, 2020). Meskipun pandemi situasi Covid-19 memberikan imbas pada jumlah orang yang direkrut, masih ada kabar baik dari berbagai perusahaan yang tetap melakukan perekrutan. Seiring dengan berjalannya waktu satu per satu perusahaan sudah mulai kembali bangkit dan berjalan menuju era new normal. Artinya, perusahaan sudah mulai beradaptasi menyesuaikan dengan keadaan pandemi dan mencari serta menerima karyawan baru. Hal ini tentunya menjadi peluang emas bagi para pencari kerja (job seeker) di masa pandemi Covid-19 ini untuk berjuang mendapatkan pekerjaan baru.

Fungsi pencantuman kualifikasi pada info lowongan pekerjaan menjadi hal yang penting. Karena hal ini bisa berdampak pada kemungkinan pembedaan kesempatan kerja (Dina Hidayani,
2016). Didapatkan data pada bulan September 2020 terdapat 10 jenis bidang pekerjaan yang masih aktif melakukan perekrutan yaitu dengan urutan pertama untuk posisi pekerjaan sebagai admin sebesar $27 \%$, diikuti dengan posisi sebagai sebagai sales atau customer service, akunting, engineering, IT, marketing, manufacturing, manajemen, transportasi dan logistik, dan banking finance (https://liputan6.com/, 2020). Posisi pekerjaan admin erat kaitannya dengan kegiatan administrasi. Yaitu meliputi pekerjaan tata usaha yang bersifat mencatat segala sesuatu yang terjadi dalam perusahaan untuk menjadi bahan keterangan bagi pimpinan perusahaan. Dengan kantor sebagai tempat penyelenggaraan kegiatan ketatausahaan tersebut yang di dalamnya terdiri atas ruangan, personil, peralatan dan operasi untuk pengelolaan informasi (Halimah, 2014). Profesi pekerjaan bidang administrasi perkantoran dikenal dengan istilah Sekretaris, Staf Admin dan Personal Assistant (https://isibandung.com/, 2015).

Purwanto, Wahyu, 2020 telah melakukan penelitian mengenai penggunaan analisis konten lowongan pekerjaan Sekretaris. Hasil penelitian menunjukkan bahwa metode analisis konten merupakan cara serbaguna untuk dapat mengidentifikasi keterampilan yang dibutuhkan oleh berbagai profesi, dan untuk menganalisis tren pasar tenaga kerja. Keterampilan yang dibutuhkan di dalam tempat kerja menjadi empat kelompok utama, yaitu: 1) kemampuan personal terdiri dari integritas, inisiatif, tanggung jawab dan dapat dipercaya, adaptasi, dan profesional, 2) kemampuan interpersonal yang meliputi kemampuan untuk bekerja di dalam sebuah tim atau kelompok, komunikasi, serta kemampuan untuk menghargai orang lain, 3) keterampilan terapan yaitu meliputi keterampilan membaca dan menulis, keterampilan matematika atau berhitung, keterampilan pengetahuan dan teknologi, serta keterampilan berpikir kritis, 4) keterampilan bekerja yang meliputi keterampilan merencanakan dan mengelola sesuatu, keterampilan untuk memecahkan masalah, keterampilan membuat keputusan, keterampilan bisnis dan industri dasar, dan keterampilan dalam menggunakan teknologi (Siti Yuliah, Krisna, 2016).

Dunbar, Kirsty; Laing, Gregory; Wynder, 2016 dalam hasil penelitiannya disampaikan bahwa perusahaan (pemberi kerja) lebih mengutamakan soft skill dalam merekrut karyawan baru. Hal ini mendapatkan prioritas utama dibandingkan keterampilan teknis yang dimiliki oleh pelamar kerja. Indikator keterampilan yang terdapat dalam iklan lowongan pekerjaan dapat digunakan sebagai indikasi awal untuk mencari pelamar kerja yang potensial (Suarta, I. M., Suwintana, I. K., Fajar Pranadi Sudana, I. G., \& Dessy Hariyanti, 2018). Eka Majida, 2019 menyatakan bahwa Jobstreet merupakan portal lowongan kerja dengan pengakses terbanyak di Indonesia dan didominasi oleh 
lowongan kerja dari Provinsi DKI Jakarta. Dalam penelitian tesebut mengenai content analysis pada iklan lowongan kerja sales di JobStreet.co.id dan Karier.com. Menggunakan variabel tingkat pendidikan formal, pengalaman, Indeks Prestasi Kumulatif, keterampilan, karakteristik pribadi, status, dan motif. Hasilnya menunjukkan bahwa Iklan lowongan kerja yang diteliti banyak yang tidak mencantumkan variabel yang digunakan pada penelitian. Iklan lowongan pekerjaan yang tidak mencantumkan variabel tersebut sekitar $>60 \%$ dari jumlah iklan yang diteliti.

Kristiana Widiawati, 2018 meneliti mengenai kompetensi Sekretaris dan Administrasi Profesional pada 10 Perusahaan di Indonesia. Memberikan hasil temuan bahwa kualifikasi minimal bagi sekretaris dan staf administrasi profesional yang harus dimiliki dan paling dicari di kalangan perusahaan itu adalah adanya kesesuaian pendidikan dengan bidang pekerjaan yang akan digelutinya, kepribadian yang menarik, kemampuan ketrampilan berkomunikasi dan kemampuan dalam penggunaan teknologi informasi perkantoran. Penelitian yang membahas dampak Covid-19 terhadap tenaga kerja di Indonesia. Memberikan hasil penelitian bahwa pandemi dapat memperburuk ketimpangan sebagian besar kelompok pekerja, selain memperburuk kondisi ekonomi masyarakat. Artinya adalah banyak rakyat Indonesia yang sudah terkena PHK kemudian terserang penyakit Covid-19 dan tidak mempunyai jaminan kesehatan sosial untuk melindungi dirinya (Syahrial, 2020).

Nurazela, 2020 melakukan penelitian mengenai kompetensi Sekretaris yang dibutuhkan di era digital. Hasilnya yaitu Sekretaris harus mempunyai kompetensi dalam memahami perkembangan teknologi. Karena perkembangan semakin canggih dan teknologi telah mampu mendisrupsi seluruh kehidupan manusia yang bisa memberikan dampak ancaman, khususnya profesi sekretaris. Pandemi Covid-19 yang melanda Indonesia membuat perusahaan-perusahaan mulai melakukan digitalisasi. Hal ini berdampak pada masa depan pasar tenaga kerja di Indonesia. Perusahaan mulai mengadopsi teknologi dan menerapkan otomatisasi karena perbatasan pergerakan manusia. Supaya dapat tetap bertahan dari kondisi ekonomi yang semakin terpuruk dan persiapan untuk menyongsong era disrupsi teknologi (https://katadata.co.id/, 2020).

Mayoritas penelitian terdahulu fokus pada analisis konten dari info lowongan pekerjaan secara umum yang tidak spesifik. Masih sangat sulit ditemukan analisis konten lowongan pekerjaan yang fokus menggunakan spesifikasi pekerjaan pada bidang administrasi perkantoran di situasi pandemi Covid-19 di Indonesia. Terdapat nilai kebaruan atau perbedaan pada penelitian yang dilakukan peneliti dibandingkan penelitian sebelumnya. Yaitu 1) Objek penelitian fokus pada bidang administrasi perkantoran meliputi profesi Sekretaris, Staf Admin, dan Personal Assistant. 2) Situs info lowongan pekerjaan yang digunakan dalam penelitian ini yaitu jobstreet.co.id, jobs.id, dan indeed. 3) Analisis konten lowongan pekerjaan dilakukan pada masa Indonesia dilanda pandemi Covid-19. 4) Metode konten info lowongan yang digunakan dalam penelitian ini berdasarkan kompetensi spesifikasi pekerjaan yaitu kemampuan personal, kemampuan interpersonal, keterampilan terapan, dan keterampilan bekerja.

Pekerjaan dalam bidang administrasi perkantoran identik dengan tugas membantu pekerjaan pimpinan perusahaan. Tugas utama Sekretaris, Staf Admin, dan Personal Assistant tidak luput dari 3 kegiatan utama yaitu 1) korespondensi (surat menyurat), 2) ekspedisi (aktivitas mencatat setiap informasi yang dikirm atau diterima), dan 3) pengarsipan (proses pengaturan dan penyimpanan informasi secara sistematis). Profesi Sekretaris, Staf Admin dan Personal Assistant harus dapat menyesuaikan dengan kebutuhan perusahaan di semua perkembangan zaman, termasuk kondisi pandemi Covid-19 dan kecanggihan teknologi. Kesenjangan Keterampilan Digital di Masa Pandemi harus dapat diminimalisir di bidang Administrasi Perkantoran. Keterampilan yang masih diragukan dimiliki oleh pelamar kerja yaitu seperti memiliki keterampilan dalam penggunaan aplikasi persuratan, penggunaan peralatan teknologi perkantoran, serta pemanfaatan media sosial dalam menunjang pekerjaan di bidang administrasi perkantoran. Sehingga rumusan masalah dalam penelitian ini terkait dengan identifikasi keterampilan berdasarkan kebutuhan perusahaan di masa pandemi Covid-19 dengan menggunakan metode analisis konten lowongan pekerjaan bidang administrasi perkantoran

\section{Metode Penelitian}

Metode yang digunakan dalam penelitian ini yaitu metode analisis konten (analisis isi). Analisis isi didefinisikan sebagai teknik mengumpulkan dan menganalisis isi dari suatu teks. Terkait dengan konten tersebut dapat berupa kata, arti (makna), gambar, simbol, ide, tema, atau beberapa pesan yang dapat dikomunikasikan (Martono, 2011). Konten analisis menafsirkan dari teks ke konteks penelitian empiris dengan membedakan analisis isi dari sebuah kajian (Krippendorff, 2004). Metode analisis konten lowongan pekerjaan dalam penelitian ini berdasarkan kompetensi spesifikasi pekerjaan yaitu kemampuan personal, kemampuan interpersonal, keterampilan terapan, dan keterampilan bekerja.

Penelitian ini adalah penelitian kualitatif. Merupakan salah satu prosedur penelitian yang menghasilkan data deskriptif. Dengan teknik analisis data kualitatif meliputi: pengumpulan data, reduksi data, penyajian data, dan penarikan kesimpulan. Teknik analisis penelitian ini secara manual dilakukan penghitungan data menggunakan 
microsoft excel untuk mengetahui distribusi jumlah dan persentase hasil data penelitian.

Obyek yang diteliti dalam penelitian ini adalah iklan lowongan pekerjaan bidang administrasi perkantoran untuk posisi Sekretaris, Staf Admin dan Personal Assistant.

Teknik purposive sampling digunakan dalam penelitian ini yaitu memenuhi kriteria 1) Info lowongan pekerjaan berasal dari situs jobstreet.co.id, jobs.id, dan indeed; 2) Periode pengumpulan data yaitu pada bulan September 2020 s.d November 2020; 3) Profesi pekerjaan yang diteliti yaitu Sekretaris, Staf Admin dan Personal Assistant; 4) Lowongan kerja berasal dari perusahaan swasta dan perusahaan pemerintah go public (Tbk). Jumlah sampel dalam penelitian berjumlah 50 buah info lowongan pekerjaan.

\section{Hasil dan Pembahasan}

Info lowongan pekerjaan bidang administrasi perkantoran yang digunakan dalam penelitian ini berjumlah 50 buah. Dengan rincian distribusi pengumpulan data selama 3 bulan (September 2020 s.d November 2020) disajikan pada tabel 1 berikut:

Tabel 1. Distribusi Info Lowongan Pekerjaan Bidang Administrasi Perkantoran

\begin{tabular}{lcc}
\hline \multicolumn{1}{c}{ Posisi } & Jumlah & Persentase \\
\hline Sekretaris & 26 & $52 \%$ \\
Staf Admin & 15 & $30 \%$ \\
Personal Asistant & 9 & $18 \%$ \\
Total & 50 & $100 \%$ \\
\hline
\end{tabular}

Sumber: Data diolah penulis (2021)

Berdasarkan tabel 1 didapatkan bahwa info lowongan pekerjaan di masa pandemi Covid-19 sesuai dengan periode penelitian paling banyak merekrut calon karyawan untuk profesi sebagai Sekretaris dengan jumlah 26 buah atau 52\%. Kemudian profesi Staf Admin dengan jumlah 15 buah atau $30 \%$ dan profesi Personal Assistant dengan jumlah 9 buah atau $18 \%$.

Distribusi lowongan kerja bidang administrasi perkantoran berasal dari 2 jenis perusahaan dengan sajian tabel 2 di bawah ini:

Tabel 2. Distribusi Perusahaan Pencari Pekerja Bidang Administrasi Perkantoran

\begin{tabular}{lcc}
\hline \multicolumn{1}{c}{ Perusahaan } & Jumlah & Persentase \\
\hline Swasta & 46 & $92 \%$ \\
Pemerintah (Tbk) & 4 & $8 \%$ \\
Total & 50 & $100 \%$ \\
\hline
\end{tabular}

Sumber: Data diolah penulis (2021)

Berdasarkan tabel 2 didapatkan bahwa perusahaan yang membuka lowongan pekerjaan pada masa pandemi Covid-19 di bidang administrasi perkantoran berasal dari perusahan swasta berjumlah 46 buah atau $92 \%$ dan berasal dari pemerintah (Tbk) berjumlah 4 buah atau $8 \%$.

Spesifikasi pekerjaan pada penelitian ini di bidang administrasi perkantoran berdasarkan 4 kelompok keterampilan yang dibutuhkan oleh perusahaan di masa pandemi Covid-19 yaitu sebagai berikut:

1. Kemampuan Personal terdiri dari integritas, inisiatif, tanggung jawab dan dapat dipercaya (jujur), adaptasi, dan profesional.

2.

Tabel 3. Distribusi Konten Kemampuan Personal

\begin{tabular}{lcccc}
\hline $\begin{array}{c}\text { Kemampuan } \\
\text { Personal }\end{array}$ & Sekretaris & $\begin{array}{c}\text { Staf } \\
\text { Admin }\end{array}$ & $\begin{array}{c}\text { Personal } \\
\text { Assistant }\end{array}$ & Total \\
\hline Integritas & 1 & - & - & 1 \\
Inisiatif & 3 & - & 1 & 4 \\
Tanggung & 1 & 4 & - & 5 \\
Jawab & & & & \\
Jujur & 3 & 4 & 1 & 8 \\
Adaptasi & - & - & 1 & 1 \\
Profesional & - & - & 1 & 1 \\
\hline
\end{tabular}

Sumber: Data diolah penulis (2021)

Berdasarkan tabel 3 didapatkan analisis konten dari info lowongan pekerjaan untuk profesi bidang administrasi perkantoran mengenai keterampilan dalam kemampuan personal para pelamar kerja yang dibutuhkan perusahaan di masa pandemi Covid-19 dan untuk menghadapi era digital. Yaitu kemampuan personal dengan jumlah yang paling banyak dibutuhkan perusahaan adalah calon karyawan yang jujur (dapat dipercaya).

Hasil ini menunjukkan bahwa calon pelamar harus memperhatikan sikap jujur sebagai syarat yang dibutuhkan dalam melamar sebuah pekerjaan. Perusahaan membutuhkan calon karyawan yang memiliki sikap jujur di masa pandemi Covid-19. Sikap jujur sangat dibutuhkan dalam semua bidang profesi administrasi perkantoran. Kejujuran merupakan salah satu kunci kesuksesan dalam bekerja. Jujur diperlukan untuk menunjukkan konsistensi antara perkataan dan perbuatan serta menjadikan dirinya sebagai orang yang selalu dapat dipercaya dalam perkataan, perbuatan dan pekerjaan. Kemampuan personal jujur menjadi salah satu dari nilai berbudi luhur, implementasi pendidikan karakter dan soft skill yang wajib dimiliki setiap calon karyawan. Sebagai contoh profesi Sekretaris, yang berasal dari bahasa latin yaitu secretum yang artinya rahasia. Kompetensi utama yang harus dimiliki Sekretaris yaitu pribadi yang dapat dipercaya (Selfiana, 2019) . Sehingga profesi ini diberi kepercayaan untuk menyimpan data yang rahasia.

Masa adaptasi new normal saat pandemi Covid-19 menjadi sebuah tantangan baru dalam perekrutan calon karyawan di dunia kerja. Perusahaan akan sangat mudah mendapatkan karyawan yang pintar, karena banyak sekali lulusan sarjana Strata 1 atau Strata 2 yang memiliki kompetensi yang sangat baik, tetapi belum tentu karyawan tersebut memiliki sikap jujur. Dengan kata lain, Sekretaris, Staf Admin, Personal Assistant 
merupakan seseorang yang sangat diharapkan bisa dipercaya untuk menyimpan data rahasia perusahaan dalam membantu pimpinan di masa pandemi Covid19 dan era digital untuk melaksanakan pekerjaannya demi tercapainya tujuan visi misi dalam sebuah perusahaan.

2. Kemampuan interpersonal yang meliputi kemampuan untuk bekerja di dalam sebuah tim atau kelompok, komunikasi, serta kemampuan untuk menghargai orang lain

Tabel 4. Distribusi Konten Kemampuan Interpersonal

\begin{tabular}{lcccc}
\hline $\begin{array}{c}\text { Kemampuan } \\
\text { Personal }\end{array}$ & Sekretaris & $\begin{array}{c}\text { Staf } \\
\text { Admin }\end{array}$ & $\begin{array}{c}\text { Personal } \\
\text { Assistant }\end{array}$ & Total \\
\hline $\begin{array}{l}\text { Bekerja dalam } \\
\text { tim }\end{array}$ & 2 & 2 & 2 & 6 \\
Komunikasi & 6 & 5 & 6 & 17 \\
$\begin{array}{l}\text { Menghargai } \\
\text { Orang lain }\end{array}$ & - & - & - & 0 \\
\hline
\end{tabular}

Sumber: Data diolah penulis (2021)

Berdasarkan tabel 4 didapatkan analisis konten dari info lowongan pekerjaan untuk profesi bidang administrasi perkantoran mengenai keterampilan dalam kemampuan interpersonal para pelamar kerja yang dibutuhkan perusahaan di masa pandemi Covid-19 dan untuk menghadapi era digital. Yaitu kemampuan interpersonal dengan jumlah yang paling banyak dibutuhkan perusahaan adalah calon karyawan yang bisa berkomunikasi dengan baik.

Hasil ini menunjukkan bahwa calon pelamar harus memiliki kemampuan komunikasi yang efektif sebagai syarat yang dibutuhkan dalam melamar sebuah pekerjaan. Perusahaan membutuhkan calon karyawan yang memiliki kemapuan berkomunikasi yang efektif di masa pandemi Covid-19. Komunikasi harus terjalin dengan baik antara karyawan dengan pimpinan perusahaan dan juga komunikasi antar sesama karyawan. Komunikasi yang dibutuhkan bersifat eksternal dan internal perusahaan. Supaya tujuan perusahaan dapat tercapai dengan baik. Terkait dengan tugas yang akan dijalankan oleh profesi Sekretaris, Staf Admin, dan Personal Assistant, sangat erat kaitannya dengan komunikasi yang efektif melalui surat menyurat (korespondensi), menerima dan menyambungkan telepon, menjadi perwakilan perusahaan saat rapat di luar perusahaan, menjadi penerima tamu dan bertugas membina hubungan yang baik dengan pihak eksternal perusahaan. Hal inilah yang mendasari pentingnya kemampuan interpersonal komunikasi dimiliki oleh calon pelamar di masa pandemi Covid-19 dan era digital.

3. Keterampilan terapan yaitu meliputi keterampilan membaca dan menulis, keterampilan matematika atau berhitung, keterampilan pengetahuan dan teknologi, serta keterampilan berpikir kritis
Tabel 5. Distribusi Konten Keterampilan Terapan

\begin{tabular}{lcccc}
\hline $\begin{array}{l}\text { Kemampuan } \\
\text { Personal }\end{array}$ & Sekretaris & $\begin{array}{c}\text { Staf } \\
\text { Admin }\end{array}$ & $\begin{array}{c}\text { Personal } \\
\text { Assistant }\end{array}$ & Total \\
\hline $\begin{array}{l}\text { Membaca } \& \\
\text { menulis }\end{array}$ & 23 & 6 & 7 & 36 \\
$\begin{array}{l}\text { Berhitung } \\
\begin{array}{l}\text { Pengetahuan } \\
\text { dan teknologi }\end{array}\end{array}$ & 18 & 1 & - & 2 \\
Berpikir kritis & - & 11 & 9 & 38 \\
\hline
\end{tabular}

Sumber: Data diolah penulis (2021)

Berdasarkan tabel 5 didapatkan analisis konten dari info lowongan pekerjaan untuk profesi bidang administrasi perkantoran mengenai keterampilan terapan para pelamar kerja yang dibutuhkan perusahaan di masa pandemi Covid-19 dan untuk menghadapi era digital. Yaitu keterampilan terapan dengan jumlah yang paling banyak dibutuhkan perusahaan adalah calon karyawan yang memiliki keterampilan pengetahuan teknologi.

Hasil ini menunjukkan bahwa calon pelamar harus memiliki kemampuan pengetahuan dan teknologi sebagai syarat yang dibutuhkan dalam melamar sebuah pekerjaan. Tidak bisa dipungkiri bahwa untuk menjadi profesional di bidang administrasi perkantoran, diperlukan pengetahuan teknologi agar dapat mengikuti perkembangan zaman yang semakin canggih. Teknologi sangat membantu pekerjaan profesi untuk semua bidang administrasi perkantoran. Menjadikan tugas-tugas menjadi lebih mudah, efektif dan efisien. Seperti surat menyurat menggunakan microsoft office dan pengiriman surat melalui electronic mail, pemesanan tiket transportasi untuk pimpinan secara online, pemesanan konsumsi rapat secara online dan sebagainya.

4. Keterampilan bekerja yang meliputi keterampilan merencanakan dan mengelola sesuatu, keterampilan untuk memecahkan masalah, keterampilan membuat keputusan, keterampilan bisnis dan industri dasar, dan keterampilan dalam menggunakan teknologi

Tabel 6. Distribusi Konten Keterampilan Bekerja

\begin{tabular}{lcccc}
\hline $\begin{array}{l}\text { Kemampuan } \\
\text { Personal }\end{array}$ & Sekretaris & $\begin{array}{c}\text { Staf } \\
\text { Admin }\end{array}$ & $\begin{array}{c}\text { Personal } \\
\text { Assistant }\end{array}$ & Total \\
\hline $\begin{array}{l}\text { Merencanakan } \\
\text { dan mengelola }\end{array}$ & - & - & - & 0 \\
$\begin{array}{l}\text { Memecahkan } \\
\text { masalah }\end{array}$ & - & - & - & 0 \\
membuat & - & - & - & 0 \\
$\begin{array}{l}\text { keputusan } \\
\text { Bisnis } \\
\text { Menggunakan }\end{array}$ & 1 & - & 2 & 2 \\
teknologi & & 2 & 2 & 5 \\
\hline
\end{tabular}

Sumber: Data diolah penulis (2021) 
Berdasarkan tabel 6 didapatkan analisis konten dari info lowongan pekerjaan untuk profesi bidang administrasi perkantoran mengenai keterampilan bekerja para pelamar kerja yang dibutuhkan perusahaan di masa pandemi Covid-19 dan untuk menghadapi era digital. Yaitu keterampilan bekerja dengan jumlah yang paling banyak dibutuhkan perusahaan adalah calon karyawan yang dapat menggunakan teknologi.

Hasil ini menunjukkan bahwa calon pelamar harus memiliki kemampuan dalam penggunaan alat-alat berbasis teknologi sebagai syarat yang dibutuhkan dalam melamar sebuah pekerjaan. Keterampilan bekerja dengan menggunakan teknologi sangat dibutuhkan oleh perusahaan di masa pandemi Covid-19 dan persiapan menyongsong era digital. Sekretaris, Staf Admin dan Personal Assistant dituntut untuk dapat memiliki kecakapan dalam penggunaan alat-alat perkantoran berbasis teknologi. Hal ini terdapat dalam konten info lowongan pekerjaan yang dibutuhkan oleh perusahaan di masa ini. Karena pekerjaan yang akan dihadapi dan dikerjakan ke depannya pasti menggunakan teknologi yang lebih canggih dari sebelumnya. Seperti rapat online dengan menggunakan aplikasi zoom atau google meet, menggunakan mesin otomatisasi perkantoran (multifungsi dalam mencetak, pindai dan membuat salinan), penggunaan sosial media dengan bijak dan tepat, dan sebagainya.

Info lowongan pekerjaan dapat membantu calon pelamar untuk mendapatkan pekerjaan. Dari hasil penelitian didapatkan bahwa beberapa aspek kemampuan soft skill dan hard skill harus dimiliki oleh calon pelamar. Terdapat beberapa persyaratan kebutuhan yang diminta oleh perusahaan dalam merekrut karyawan baru. Sikap soft skill yang wajib dimiliki oleh calon pelamar yaitu sifat jujur dan memiliki kemampuan komunikasi yang baik dan efektif. Selain itu dari aspek hard skill diperlukan kemampuan memiliki pengetahuan teknologi serta dapat mengoperasikan alat-alat berbasis teknologi. Hal ini dapat menjadi perhatian bagi calon pelamar untuk dapat memiliki soft skill dan hard skill tersebut supaya dapat diterima menjadi karyawan baru sebuah perusahaan sebagai profesi Sekretaris atau Staf Admin atau Personal Assistant. Sehingga dengan harapan jumlah angka pengangguran menjadi menurun di masa pandemi Covid-19.

\section{Kesimpulan}

Virus Covid-19 di Indonesia belum berakhir. Adaptasi dalam kehidupan new normal sudah mulai dilakukan. Salah satunya oleh perusahaanperusahaan dalam menjamin keberlangsungan usaha dengan mengutamakan kesehatan dan keselamatan karyawan. Kebutuhan perusahaan akan calon tenaga kerja di masa pandemi Covid-19 dan era teknologi digital mengalami penyesuaian. Tercermin dalam konten lowongan pekerjaan dari situs online.
Didapatkan bahwa pemetaan kebutuhan perusahaan dalam bidang administrasi perkantoran untuk profesi Sekretaris, Staf Admin, dan Personal Assistant dapat diidentifikasikan ke dalam kemampuan personal dibutuhkan kejujuran sebagai faktor utama yang diperlukan dalam bekerja, pada kemampuan interpersonal dibutuhkan kemampuan komunikasi yang efektif dari calon tenaga kerja, sedangkan dari keterampilan terapan dibutuhkan oleh perusahaan kepada calon pelamarnya untuk memiliki pengetahuan dan teknologi, serta pada keterampilan bekerja sangat diperlukan dalam kondisi pandemi Covid-19 dan era digital ini yaitu calon karyawan yang dapat menggunakan teknologi. Keterbatasan riset ini menggunakan analisa kualitatif. Berdasarkan hal tersebut rekomendasi untuk penelitian berikutnya dapat menggunakan metode analisa kuantitatif. Peluang riset ke depannya dapat menggunakan periode pengumpulan data yang lebih panjang yang dapat digunakan oleh calon pelamar dalam memperhatikan kebutuhan perusahaan dalam merekrut karyawan baru.

\section{Referensi}

Dina Hidayani, D. K. (2016). Analisis Kesempatan Kerja Yang Dibutuhkan dalam Perekrutan Karyawan di Batam yang Menggunakan Iklan Lowongan Pekerjaan di Media Koran Batam Pos dan Tribun Batam. Jurnal Akuntansi, Ekonomi Dan Manajemen Bisnis, 4(2), 115121.

Dunbar, Kirsty; Laing, Gregory; Wynder, M. (2016). A Content Analysis of Accounting Job Advertisements: Skill Requirements for Graduates. E-Journal of Business Education \& Scholarship of Teaching, 10(1), 28-72.

Eka Majida, I. S. (2019). Analisis Lowongan Pekerjaan. Seminar Nasional Official Statistics.

Halimah, M. (2014). Administrasi Perkantoran (2nd ed.). Universitas Terbuka.

https://bps.go.id. (2020). Badan Pusat Statistik.

https://cnnindonesia.com/. (2020). Cable News Network Indonesia.

https://covid19.go.id/. (2021). Kementerian Kesehatan Republik Indonesia. Satuan Petugas Covid-19.

https://isibandung.com/. (2015). Ikatan Sekretaris Indonesia-Bandung.

https://katadata.co.id/. (2020). Komunikasi dan Informasi.

https://liputan6.com/. (2020). Kapanlagi Youniverse. https://merdeka.com/. (2020). Kapanlagi Youniverse.

Krippendorff. (2004). Content analysis: an introduction to its methodology. Sage Publication.

Kristiana Widiawati, S. (2018). Kompetensi dan Kebutuhan Sekretaris dan Administrasi Profesional Terkini di Sepuluh Perusahaan 
Indonesia. Jurnal Ikraith-Humaniora, 2(2), 24-30.

Martono, N. (2011). Penelitian Kuantitatif. Raja Grafindo Persada.

Nurazela, T. W. (2020). Studi Kebutuhan IT Literature Terhadap Profesi Non IT. Jurnal Universitas Internasional Batam, 1(1), 475486.

Purwanto, Wahyu, Y. (2020). Identifikasi Kebutuhan Keterampilan Sekretaris Melalui Analisis Konten Lowongan Pekerjaan. Jurnal Economia, 16(1), 44-55.

Selfiana. (2019). Kompetensi Minimal Profesi Sekretaris Direksi di Sepuluh Perusahaan Indonesia. Jurnal Efisiensi-Kajian Ilmu Administrasi, XVI(2), 22-38.

Siti Yuliah, Krisna, D. S. (2016). Analisis
Kebutuhan Penggunaan Bahasa Inggris Melalui Iklan Lowongan Pekerjaan di Media Cetak. Jurnal Bahasa Inggris Terapan, 2(2), 39-51.

Suarta, I. M., Suwintana, I. K., Fajar Pranadi Sudana, I. G., \& Dessy Hariyanti, N. K. (2018). Employability Skills for Entry Level Workers: A Conten Analysis of Job Advertisement in Indonesia. Journal of Technical Educational and Training. Journal of Technical Educational and Training, 10(2), 49-61.

Syahrial. (2020). Dampak Covid-19 Terhadap Tenaga Kerja di Indonesia. Jurnal Ners, 4(2), 21-29. 